\title{
Implementasi Kebijakan Penyediaan Ruang Terbuka Hijau Perumahan di Kawasan Perkotaan Kabupaten Sleman
}

\author{
Sintha Prima Widowati \\ Program Studi Teknik Lingkungan UPN "Veteran" Yogyakarta \\ Email: sintha.widowati@upnyk.ac.id
}

\begin{abstract}
Abstrak
Perubahan pemanfaatan lahan menjadi perumahan yang tidak terkendali di Kelurahan Condongcatur dapat mengancam pelestarian sumberdaya air di Kabupaten Sleman dengan adanya konflik meningkatnya ruang terbangun versus berkurangnya lahan Ruang Terbuka Hijau (RTH) karena kelurahan tersebut berada di kawasan yang berpotensi menjadi Kawasan Resapan Air di Kabupaten Sleman. Penelitian ini bertujuan memberikan gambaran sejauh mana penyediaan $R T H$ di perumahan untuk mengetahui implementasi kebijakan penyediaan RTH oleh pengembang perumahan di kawasan perkotaan khususnya di Kelurahan Condongcatur, Kecamatan Depok, Kabupaten Sleman. Penelitian dilakukan secara deskriptif dengan metode gabungan kuantitatif-kualitatif menggunakan Stratified Proportional Random Sampling. Hasilnya prosentase penyediaan RTH di setiap sampel perumahan $\leq 25 \%$ sehingga implementasi kebijakan penyediaan RTH oleh pengembang Tidak Sesuai dengan peraturan yang berlaku yaitu Peraturan Bupati Sleman Nomor 11 Tahun 2007 tentang Pengembangan Perumahan. Namun hingga saat ini belum terlihat adanya hukuman atau sanksi terhadap ketidakpatuhan pengembang karena dalam dalam peraturan belum dicantumkan sanksi yang jelas. Peraturan itu sebaiknya dikaji ulang dan dilengkapi dengan tata cara implementasi serta sanksi yang jelas terhadap pelanggaran.
\end{abstract}

Kata kunci : implementasi kebijakan, penyediaan RTH, pengembangan perumahan, pelestarian sumberdaya air

\section{PENDAHULUAN}

Kecamatan Depok merupakan salah satu wilayah di Kabupaten Sleman yang berbatasan langsung dengan Kota Yogyakarta sebagai pusat perkembangan dan pertumbuhan ekonomi sehingga berkembang pesat menjadi kawasan perkotaan, ditandai dengan laju perubahan pemanfaatan lahan agraris ke non-agraris yang relatif cepat (Yunus, 2005). Salah satu perubahan pemanfaatan lahan yang sangat signifikan adalah pesatnya perkembangan perumahan. Laju peningkatan jumlah perumahan di Kecamatan Depok memicu kenaikan harga tanah secara umum di Daerah Istimewa Yogyakarta dengan kenaikan harga tanah tertinggi di Kecamatan Depok terutama Kelurahan Condongcatur dan Kelurahan Caturtunggal. Dari awal tahun 1970an sampai tahun 2012, harga tanah di kedua kelurahan tersebut meningkat sekitar 5-10 kali lipat. Namun hal tersebut tidak menyurutkan permintaan perumahan di Kecamatan Depok. Secara umum di Kabupaten Sleman sampai dengan tahun 2012, Dinas Pengendalian Pertanahan Daerah (DPPD) Kabupaten Sleman mencatat terdapat lebih dari 700 lokasi perumahan dengan skala kecil, menengah dan besar pada tahun 2004 - 2009, ditambah kurang lebih 100 izin pemanfaatan tanah untuk perumahan pada tahun 2010 - 2012 (DPPD Kabupaten Sleman, 2012; Wiryawan, 2012). 
Di dalam Dokumen Rencana Tata Ruang Wilayah (RTRW) Kabupaten Sleman Tahun 2009-2028, Kecamatan Depok dinyatakan berada di luar Kawasan Resapan Air di Kabupaten Sleman. Padahal dilihat dari aspek geologinya, wilayah Kecamatan Depok terbentuk oleh Formasi Merapi Muda yang merupakan formasi batuan yang sama dengan yang berada di wilayah yang telah ditentukan sebagai Kawasan Resapan Air di Kabupaten Sleman (Gambar 1).

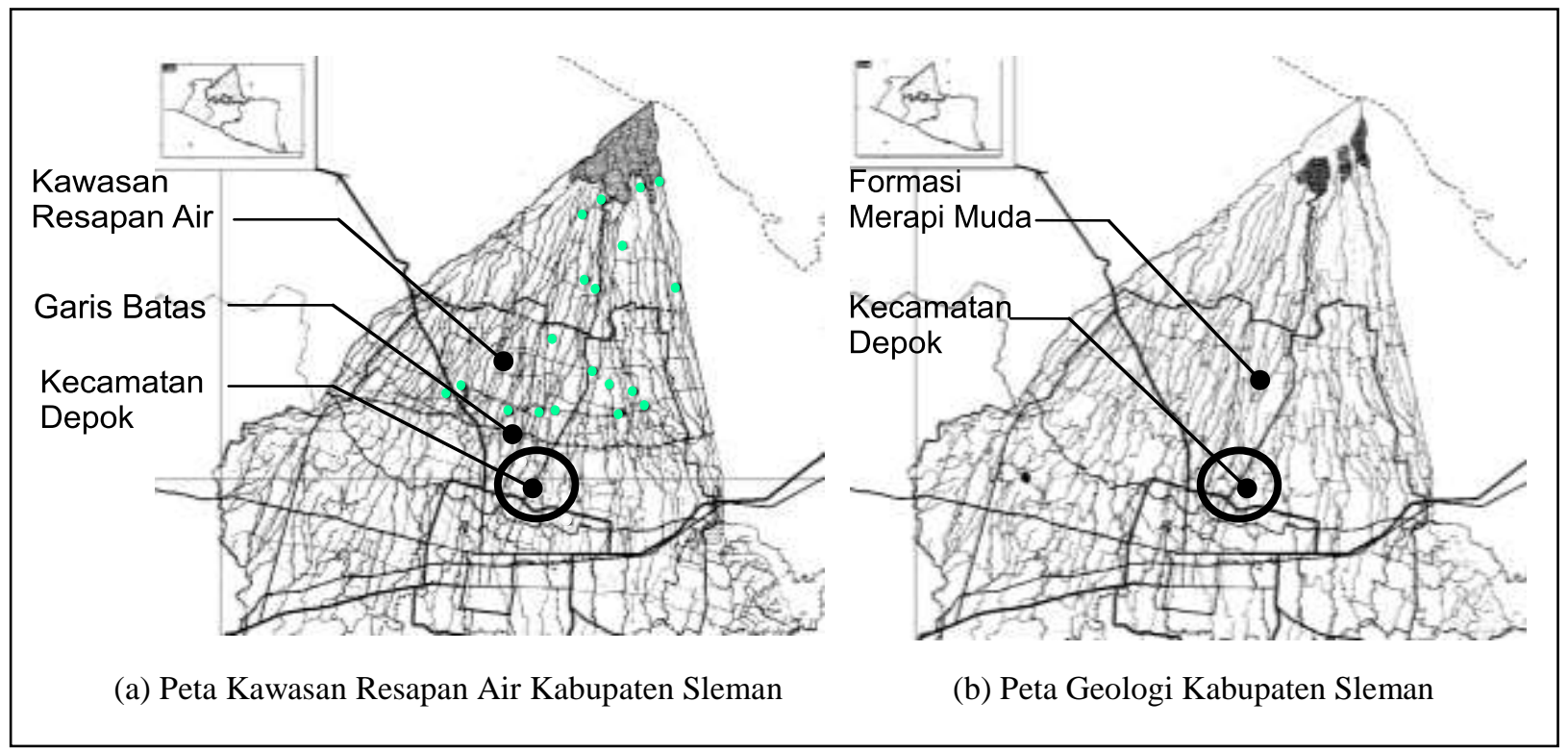

Sumber: Rencana Tata Ruang Kabupaten Sleman 2009-2028, dengan modifikasi

Gambar 1. Kecamatan Depok Berada pada Formasi Batuan yang sama dengan Kawasan yang telah ditetapkan sebagai Kawasan Resapan Air

Formasi Merapi Muda terjadi dari hasil aktivitas vulkanik yang merupakan material yang sangat baik sebagai akuifer yang mampu menyimpan cadangan airtanah dalam jumlah besar sehingga berpotensi besar menjadi Kawasan Resapan Air. Potensi tersebut sangat signifikan karena kondisi airtanah di Kabupaten Sleman adalah yang terbaik di Provinsi Daerah Istimewa Yogyakarta (BAPPEDA Sleman, 2006) sehingga perubahan pemanfaatan lahan menjadi perumahan harus dilakukan dengan tetap mengutamakan pelestarian sumberdaya air.

Permasalahan perubahan lahan yang dapat mengancam pelestarian sumberdaya air adalah adanya konflik ruang terbangun versus Ruang Terbuka Hijau (RTH) yaitu perubahan lahan menjadi ruang terbangun yang tidak terkendali sehingga mengalahkan keberadaan RTH yang berperan secara signifikan dalam proses daur hidup sumberdaya air yang biasa disebut dengan daur hidrologi. Apabila konflik tersebut terjadi terus-menerus dalam jangka waktu lama, dampak yang terjadi adalah berkurangnya cadangan airtanah pada musim kemarau dan tingginya frekuensi banjir permukaan pada musim hujan. Masalah tersebut dapat dihindari apabila perubahan lahan menjadi 
ruang terbangun tetap seimbang dengan keberadaan RTH (Dwiyanto, 2009; Kodoatie dan Sjarief, 2010).

Noviandri (2012) telah menemukan bahwa pembangunan perumahan di Kabupaten Sleman cenderung tidak disertai dengan penyediaan Ruang Terbuka Hijau (RTH) sehingga dapat menyebabkan berkurangnya pasokan air bagi Kawasan Resapan Air maupun kawasan-kawasan di bawahnya. Pertanyaan yang muncul adalah sejauh mana penyediaan RTH di perumahan telah dilakukan dan berapa persen luasan RTH di perumahan yang telah disediakan oleh para developer pada berbagai tipe perumahan.

Secara umum, penelitian mengenai penyediaan RTH di perumahan telah dilakukan oleh Amin \& Amri (2011) dan Nurdiansyah (2012) namun jumlah luasannya mengacu pada UU No.26 Tahun 2007 tentang Penataan Ruang yang memberikan angka prosentase kebutuhan luasan RTH pada suatu luasan wilayah kota sehingga perhitungan yang dilakukan belum mencerminkan kondisi penyediaan RTH perumahan yang sesungguhnya. Dalam hal ini Pemerintah Kabupaten Sleman telah memiliki peraturan khusus yang menjadi rambu-rambu perubahan tata guna lahan untuk pembangunan perumahan baik di dalam maupun di luar Kawasan Resapan Air di Kabupaten Sleman, yaitu Peraturan Bupati Sleman Nomor 11 Tahun 2007 tentang Pengembangan Perumahan.

Oleh karena itu diperlukan penelitian yang dapat memberikan gambaran sejauh mana penyediaan RTH perumahan di Kabupaten Sleman dilaksanakan untuk mengetahui implementasi kebijakan penyediaan RTH oleh pengembang di perumahan-perumahan berizin di kawasan perkotaan khususnya di Kelurahan Condongcatur, Kecamatan Depok, Kabupaten Sleman.

\section{TINJAUAN PUSTAKA}

\section{Ruang Terbuka Hijau (RTH)}

Ruang Terbuka Hijau (RTH), menurut Undang-Undang No. 26 tahun 2007 adalah suatu area memanjang/berbentuk jalur dan/atau mengelompok, yang penggunaannya lebih bersifat terbuka, tempat tumbuh tanaman, baik yang tumbuh secara alamiah maupun yang sengaja ditanam. Sedangkan Peraturan Menteri Dalam Negeri Nomor 1 Tahun 2007 Tentang Penataan Ruang Terbuka Hijau Kawasan Perkotaan mengamanatkan Ruang Terbuka Hijau Kawasan Perkotaan (RTHKP) sebagai bagian dari ruang terbuka suatu kawasan perkotaan yang diisi oleh tumbuhan dan tanaman guna mendukung manfaat ekologi, sosial, budaya, dan ekonomi. 
Undang-Undang No. 26 tahun 2007 mengklasifikasikan RTH menjadi 2, yaitu: RTH publik dan RTH privat. RTH publik merupakan RTH yang dimiliki dan dikelola oleh pemerintah daerah kota dan dapat digunakan untuk kepentingan masyarakat secara umum, misalnya taman kota, taman pemakaman umum, dan jalur hijau sepanjang jalan, sungai, dan pantai. Sedangkan RTH privat adalah RTH yang dimiliki dan dikelola oleh individu/kelompok baik secara komersil maupun non komersil sehingga akses pemanfaatannya pun tergantung pada pengaturan oleh individu/kelompok tersebut. Contoh RTH privat antara lain kebun/taman pada halaman rumah pribadi atau pada gedung milik masyarakat umum maupun institusi swasta. Berdasarkan klasifikasi tersebut, dalam hal ini, taman lingkungan perumahan dan permukiman merupakan salah satu jenis RTH privat karena dimiliki dan dikelola oleh pengembang perumahan dan akses pemanfaatannya tidak mutlak secara umum.

Berkaitan dengan upaya pelestarian sumberdaya air, RTH di lingkungan perumahan dapat memiliki fungsi yang signifikan sebagai berikut: (1) Pengamanan keberadaan kawasan lindung perkotaan; (2) Pengendali pencemaran dan kerusakan tanah, air dan udara; (3) Memperbaiki iklim mikro; (4) Meningkatkan cadangan oksigen; dan (5) Pengendali sistem tata air (Fandeli dkk, 2004; Noor, 2006; Nandi, 2008; Asdak, 2010; dan Kodoatie dan Sjarief, 2010). Manfaat tambahan RTH di lingkungan perumahan antara lain dapat menjadi: (1) Sarana rekreasi aktif dan pasif serta interaksi sosial; (2) Sarana aktivitas sosial bagi anak-anak, remaja, dewasa dan manula; dan (3) Sarana ruang evakuasi untuk keadaan darurat (PerMendagri No.1, 2007).

\section{Daur Hidrologi}

Daur hidrologi merupakan proses reproduksi air jangka panjang secara alami di bumi, yang bergerak dari laut ke atmosfer kemudian turun ke permukaan tanah sebagai curah hujan dan kemudian kembali lagi ke laut melalui mataair dan sungai. Secara umum daur hidrologi dapat dijabarkan sebagai berikut: air di laut mengalami evaporasi akibat energi panas matahari sehingga menjadi uap air yang kemudian terbawa angin ke daratan dan udara. Sebagian dari uap air tersebut akan terkondensasi menjadi kumpulan awan di udara yang kemudian apabila telah jenuh akan turun sebagai curah hujan ke permukaan tanah. Sebelum mencapai permukaan tanah, air hujan yang turun ke bumi dapat tertampung sementara oleh tajuk vegetasi (interception). Air tersebut dapat turun ke tanah melalui sela-sela daun (throughfall), dapat juga terserap oleh daunnya dan kemudian dialirkan kembali ke tanah melalui batang pohon (stemflow), dan dapat juga tidak turun ke tanah karena tinggal di daun dan terevaporasi kembali ke atmosfer. Air hujan yang jatuh di permukaan tanah 
akan terserap ke dalam tanah melalui proses infiltrasi. Air hujan yang tidak terserap oleh tanah akan tertampung sementara pada cekungan-cekungan permukaan tanah kemudian mengalir ke tempat yang lebih rendah dan selanjutnya masuk ke badan air terdekat (sungai, danau, waduk) yang akhirnya mengalir kembali ke laut lepas secara alami. Air hujan yang terinfiltrasi ke dalam lapisan tanah akan membentuk kelembaban tanah. Apabila telah mencapai titik jenuh, air akan bergerak lebih jauh secara vertikal ke dalam lapisan batuan yang bernama akifer yang bersifat impermeable sehingga terkumpul menjadi airtanah (groundwater). Airtanah bergerak secara horizontal menuju tempat yang lebih rendah hingga terkadang dapat muncul ke permukaan tanah sebagai mata air (springs, seepage). Pada musim kemarau airtanah akan mengalir secara perlahan-lahan ke badan air terdekat sehingga tidak akan terjadi kekeringan (Asdak, 2010).

Untuk mempelajari faktor-faktor yang mempengaruhi daur hidrologi, Kodoatie dan Sjarief (2010) memetakan proses daur hidrologi pada ruang-ruang di bumi mengacu pada pembagian ruang di UU No.26 Tahun 2007 tentang Penataan Ruang yaitu Ruang Laut, Ruang Darat dan Ruang Udara. Daur hidrologi banyak terjadi di Ruang Darat dengan dipengaruhi oleh banyak faktor, antara lain iklim, energi panas matahari, vegetasi dan jenis permukaan tanah/tutupan lahan, jenis struktur lapisan batuan di bawah permukaan bumi, topografi wilayah dan kemiringan lereng, serta aktivitas manusia (Noor, 2006; Asdak, 2010; dan Kodoatie dan Sjarief, 2010). Dari berbagai macam faktor tersebut, faktor aktivitas manusia dirasakan yang paling mempengaruhi proses daur hidrologi yang terjadi saat ini karena aktivitas manusia yang akan mempengaruhi kesemua faktor yang berkaitan dengan daur hidrologi. Dalam hal ini, faktor aktivitas manusia yang paling menentukan adalah aktivitas yang berkaitan dengan perubahan tata guna lahan di Ruang Darat yang tidak terkendali akibat meningkatnya pertumbuhan penduduk secara signifikan.

\section{Pengaruh Perubahan Tata Guna Lahan Terhadap Daur Hidrologi}

Meningkatnya jumlah penduduk di dunia menyebabkan peningkatan dalam pemenuhan kebutuhan pokok maupun sekunder. Hal ini memicu terjadinya eksploitasi lahan yang berlebihan tanpa memikirkan dampaknya terhadap lingkungan dan sumberdaya alam sebagai modal dasar pembangunan untuk jangka panjang. Eksploitasi berlebihan mampu mengubah tata guna lahan dari bentanglahan alami menjadi bentang budidaya yang dirasa memiliki nilai ekonomi lebih tinggi daripada nilai sumberdaya alami. Fenomena ini juga terjadi pada sumberdaya air yang oleh Kodoatie dan Sjarief (2010) disebut dengan konflik kepentingan dan kebutuhan antara manusia versus air. Salah satunya adalah konflik ruang terbangun versus ruang terbuka hijau (RTH) yang 
biasanya menjadi pemicu kerentanan kualitas dan kuantitas cadangan airtanah maupun pemicu bencana banjir di kawasan perkotaan.

Dalam daur hidrologi telah dijelaskan bahwa air hujan yang turun ke bumi akan terserap ke tanah melalui proses infiltrasi, sehingga jenis tutupan permukaan tanah akan sangat mempengaruhi proses infiltrasi tersebut. Apabila tutupan permukaan tanah tersebut seperti hutan ataupun lahan pertanian, tentunya proses infiltrasi bisa berjalan dengan lancar. Namun, apabila tutupan permukaan tanah bersifat kedap air seperti beton ataupun aspal maka proses infiltrasi tidak akan berjalan dengan baik. Rendahnya prosentase RTH di ruang terbangun akan membatasi proses infiltrasi pada daerah resapan air sehingga air hujan yang turun ke permukaan akan diloloskan menjadi limpasan permukaan yang berlebihan (run-off overflow) yang berpotensi menimbulkan banjir di perkotaan (Noor, 2006; Asdak, 2010; dan Kodoatie dan Sjarief, 2010).

Kodoatie dan Sjarief (2010) menggambarkan pengaruh perubahan tata guna lahan tersebut secara kuantitatif dengan hutan sebagai titik nol penanda lingkungan alami. Apabila sebuah hutan di sebuah Daerah Aliran Sungai (DAS) diubah untuk pemanfaatan lain maka akan terjadi peningkatan signifikan pada debit puncak sungainya. Misalnya ketika diubah menjadi kawasan permukiman maka debit puncaknya akan meningkat sebesar 5 sampai 20 kali tergantung jenis hutan dan jenis kawasan permukimannya. Peningkatan debit puncak sungai paling sedikit terjadi bila hutan diubah menjadi rerumputan dan peningkatan paling besar terjadi apabila hutan diubah menjadi lahan perkerasan beton atau aspal. Dengan demikian terlihat jelas apabila pembangunan perumahan tidak disertai dengan penyediaan RTH maka dikhawatirkan terjadi peningkatan debit limpasan permukaan karena adanya permukaan yang sudah kedap air. Hal ini tentunya juga mempengaruhi keberlanjutan kuantitas dan kualitas sumberdaya air di bumi.

\section{Kebijakan Kuantitas RTH Di Kabupaten Sleman}

Luas ruang terbuka hijau (RTH) yang ideal di suatu kota berdasarkan UU No. 26 Tahun 2007 disebutkan paling sedikit $30 \%$ dari luas wilayah kota tersebut, yang terbagi menjadi proporsi luas RTH publik paling sedikit $20 \%$ dari luas wilayah kota dan luas RTH privat paling sedikit 10\% dari luas wilayah kota. Prosentase ini biasanya menjadi acuan penyediaan RTH di perumahan di berbagai kota di Indonesia Amin \& Amri, 2011 dan Nurdiansyah, 2012).

Namun demikian, Pemerintah Kabupaten Sleman telah memiliki peraturan khusus mengenai penyediaan RTH di perumahan yang tertuang dalam Peraturan Bupati Sleman Nomor 11 Tahun 
2007 tentang Pengembangan Perumahan. Berdasarkan peraturan tersebut, kebijakan penyediaan RTH di perumahan dibagi menjadi perumahan di dalam dan di luar Kawasan Resapan Air. Karena Kelurahan Condongcatur berada di luar Kawasan Resapan Air maka kebijakan yang berlaku adalah ketentuan sebagai berikut:

1. Luasan kavling minimal $125 \mathrm{~m}^{2}$;

2. Nilai Koefisien Dasar Bangunan (KDB) yaitu koefisien perbandingan antara luas lantai dasar bangunan gedung dengan persil/ kavling, sebesar maksimal 50\%;

3. Nilai Koefisien Tutupan Lahan Kavling (KTLK) yaitu perbandingan antara luas bangunan dan bangunan gedung yang menutup tanah terhadap luas kavling, sebesar maksimal 80\%; dan

4. Nilai Koefisien Tutupan Lahan Lingkungan (KTLL) yaitu perbandingan antara luas bangunan dan bangunan gedung yang menutup tanah terhadap luas lahan perumahan, sebesar maksimal $70 \%$.

Berdasarkan ketentuan-ketentuan tersebut dapat diketahui bahwa angka prosentase luas RTH yang harus disediakan di masing-masing unit kavling rumah di suatu perumahan dilihat dari ketentuan luas kavling minimal dan ketentuan nilai KDB. Bagi perumahan yang berada di luar Kawasan Resapan Air, luas kavling minimal yang diperbolehkan adalah $125 \mathrm{~m}^{2}$. Nilai KDB maksimal yang diperbolehkan adalah 50\% sehingga prosentase luas RTH minimal yang harus disediakan di setiap kavling adalah (100\% -50\%) dari luas kavling. Jadi, menurut Peraturan Bupati Sleman Nomor 11 Tahun 2007 tentang Pengembangan Perumahan, prosentase luasan RTH di tiap unit kavling yang seharusnya diimplementasikan di perumahan oleh developer di Kelurahan Condongcatur, Depok, Sleman adalah sebesar 50\% dari luas kavling, dengan luas kavling minimal $125 \mathrm{~m}^{2}$.

\section{METODE PENELITIAN}

Penelitian ini merupakan penelitian deskriptif dengan metode gabungan kuantitatif-kualitatif menggunakan data primer dan data sekunder. Lokasi penelitian yaitu pada perumahan berizin di Kelurahan Condongcatur, Kecamatan Depok, Kabupaten Sleman, Daerah Istimewa Yogyakarta. Kelurahan Condongcatur dipilih menjadi lokasi penelitian karena merupakan area yang laju pemanfaatan lahannya menjadi lahan terbangun sangat cepat, padahal kelurahan tersebut memiliki formasi batuan yang sama dengan area yang termasuk Kawasan Resapan Air Kabupaten Sleman 
dan kelurahan tersebut berada sangat dekat dengan garis batas Kawasan Resapan Air Kabupaten Sleman. Kedua alasan penting tersebut yang mendasari dilakukannya penelitian mengenai implementasi penyediaan RTH perumahan di wilayah Kelurahan Condongcatur, Depok, Sleman, Daerah Istimewa Yogyakarta.

\section{Tahapan Penelitian}

\section{Tahap Persiapan}

Tahap persiapan merupakan tahap awal penelitian untuk menentukan tipe dan jumlah perumahan yang dapat digunakan sebagai sampel untuk pengumpulan data primer. Selain data primer, di tahap persiapan juga dilakukan pengumpulan data sekunder berupa daftar perumahan berijin di Kelurahan Condongcatur, dokumen Peraturan Bupati Sleman Nomor 11 Tahun 2007 tentang Pengembangan Perumahan, dokumen peraturan dan perundangan serta laporan-laporan yang terkait dengan implementasi peraturan tersebut. Tahap persiapan ini dilakukan di laboratorium karena memerlukan komputer untuk mengakses data sekunder melalui jaringan internet.

Jumlah sampel penelitian ditentukan menggunakan metode Stratified Proportional Random Sampling. Untuk itu, pertama perlu diketahui populasi perumahan di Kelurahan Condongcatur yang diambil dari data sekunder di website resmi Pemerintah Kabupaten Sleman berupa daftar perumahan berizin mulai tahun 2007. Tahun tersebut ditetapkan berdasar tahun terbitnya peraturan mengenai penyediaan RTH di kawasan perkotaan (Undang-undang No.26 Tahun 2007 tentang Penataan Ruang dan diturunkan pada Peraturan Bupati Sleman Nomor 11 Tahun 2007 tentang Pengembangan Perumahan) sehingga diasumsikan kewajiban penyediaan RTH baru diwajibkan secara legal mulai tahun 2007. Jumlah perumahan yang terkumpul dianggap sebagai populasi dalam penelitian ini. Setelah populasi perumahan diketahui, survei dan pengamatan awal di lapangan dilakukan untuk mengetahui koordinat lokasi perumahan menggunakan GPS dan mengamati jumlah unit dan luas kavling pada seluruh populasi perumahan. Populasi perumahan kemudian distrata menjadi beberapa tingkatan tipe berdasarkan luas kavlingnya. Untuk mendapatkan jumlah sampel yang proporsional pada setiap tingkatan tipe kavling yang ada, prosentase proporsi sampel pada masing-masing tipe kavling perlu dihitung. Jumlah total sampel proporsional didapat dari angka prosentase tersebut dikalikan jumlah total unit kavling pada tiap tipe kavling. Kemudian untuk mendapatkan angka jumlah sampel unit kavling yang akan diambil secara acak pada tiap perumahan dengan tipe kavling sama, prosentase jumlah unit kavling tiap perumahan yang memiliki tipe kavling sama perlu dihitung. Angka prosentase 
tersebut dikalikan dengan jumlah total sampel proporsional tiap tipe kavling untuk mendapatkan angka jumlah sampel acak unit kavling di setiap perumahan. Rumus untuk menghitung besarnya sampel secara proporsional untuk tiap tipe kavling adalah sebagai berikut:

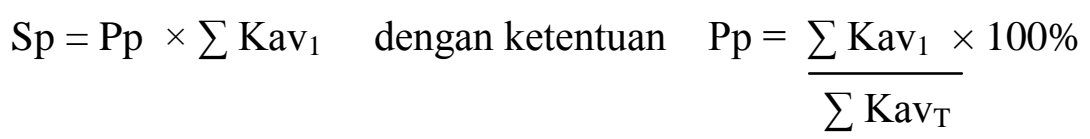

Keterangan:

Sp : Besar sampel proporsional

Pp : Prosentase sampel proporsional pada setiap tipe kavling

$\sum$ Kav1 : Jumlah unit kavling pada 1 tipe kavling

$\sum$ KavT : Jumlah total unit kavling pada seluruh tipe kavling

Kemudian rumus untuk menghitung besarnya jumlah sampel acak unit kavling di tiap perumahan yang memiliki tipe kavling sama adalah sebagai berikut:

$$
\mathrm{Sa}=\mathrm{Pa} \times \mathrm{Sp} \quad \text { dengan ketentuan } \mathrm{Pa}=\frac{\sum \mathrm{U}_{1} \times 100 \%}{\sum \mathrm{U}_{\mathrm{T}}}
$$

Keterangan:

Sa : Besar sampel acak

$\mathrm{Pa}$ : Prosentase sampel acak pada setiap perumahan

$\sum \mathrm{U} 1$ : Jumlah unit kavling pada 1 perumahan

$\sum$ UT : Jumlah total unit kavling pada perumahan dengan tipe kavling sama

Pendataan sampel penelitian akan dipresentasikan pada tabel seperti Tabel 1 berikut ini.

Tabel 1. Contoh Pendataan Sampel Perumahan

\begin{tabular}{cccccccc}
\hline No. & $\begin{array}{c}\text { Nama } \\
\text { Perumahan }\end{array}$ & $\begin{array}{c}\text { Tipe } \\
\text { Kavling } \\
\text { Terstrata }\end{array}$ & $\begin{array}{c}\text { Jumlah } \\
\text { Kavling }\end{array}$ & $\begin{array}{c}\text { Total } \\
\text { Unit } \\
\text { Kavling } \\
\text { per Tipe }\end{array}$ & $\begin{array}{c}\text { Prosentase } \\
\text { Proporsi } \\
\text { Sampel }\end{array}$ & $\begin{array}{c}\text { Jumlah } \\
\text { Sampel } \\
\text { Acak }\end{array}$ & $\begin{array}{c}\text { Total } \\
\text { Sampel } \\
\text { Acak } \\
\text { per Tipe }\end{array}$ \\
\hline 1. & $\ldots$ & $\ldots$ & $\ldots$ & $\ldots$ & $\ldots$ & $\ldots$ & $\ldots$ \\
\hline & Jumlah & & & $\ldots$ & & & \\
\hline
\end{tabular}




\section{Tahap Pelaksanaan}

Tahap ini merupakan tahap pengumpulan data primer di lapangan menggunakan metode survei dan wawancara. Berbekal informasi mengenai lokasi perumahan dari data sekunder, pertamatama survei awal untuk menentukan sampel secara Stratified Proportional Random Sampling dilakukan dengan membawa GPS dan kompas untuk mengetahui koordinat lokasi setiap sampel perumahan, mengukur luas kavling rumah menggunakan alat ukur digital serta menghitung jumlah kavling rumah di tiap perumahan. Kemudian setelah besaran sampel proporsional ditentukan, sampel rumah di lapangan diambil secara acak sesuai jumlah yang telah dihitung. Pengukuran luasan RTH dan luas kavling pada tiap sampel dilakukan menggunakan alat ukur digital. Selain itu, kamera digunakan untuk mendokumentasikan data-data lapangan yang diperlukan. Selain itu, wawancara juga dilakukan dengan pihak-pihak terkait termasuk pemilik rumah yang dijadikan sampel untuk mengetahui wewenang pemanfaatan dan pengelolaan RTH di perumahan.

\section{Tahap Analisis dan Pengolahan Data}

Analisis dan pengolahan data primer dilakukan menggunakan metode pemetaan dan statistik sederhana. Pertama-tama, koordinat lokasi perumahan berdasarkan hasil pengumpulan data di lapangan diplotkan pada Peta Dasar dari Peta Rupa Bumi Indonesia berskala 1:25000 untuk dibuat Peta Lokasi Sampel Perumahan. Peta tersebut kemudian diturunkan menjadi berskala 1:5000 hingga 1:1000 untuk mendapatkan kondisi spasial yang lebih detail sehingga dapat menunjukkan gambar siteplan perumahan serta luasan RTH yang diimplementasikan pada sampel rumah. Data spasial yang diperoleh dari pemetaan kemudian dikuantifikasi dengan statistik sederhana untuk mendapatkan angka rata-rata prosentase luasan RTH yang terimplementasi pada tiap tipe perumahan. Tahap ini dilakukan di laboratorium menggunakan seperangkat komputer yang berisi program-program tertentu seperti ArcView untuk pemetaan dan Ms.Excel untuk statistik sederhana.

\section{Tahap Analisis Hasil}

Tahap analisis hasil dilakukan untuk mengkaji hasil pengolahan data primer yang akan dibandingkan dengan standar baku yang didapat dari data sekunder. Hasil perhitungan prosentase luasan RTH terimplementasi dikelompokkan sesuai kriteria sesuai dan tidak sesuai dengan kebijakan penyediaan RTH masing-masing tipe perumahan. Kriteria tersebut disusun berdasarkan kebijakan standar penyediaan RTH di perumahan yang ada di Kabupaten Sleman dalam Peraturan Bupati Sleman Nomor 11 Tahun 2007 tentang Pengembangan Perumahan. 
Prosentase luas RTH di tiap kavling optimal yang harus disediakan adalah 50\% dari luas kavling, dengan syarat minimal luas kavling adalah $125 \mathrm{~m}^{2}$. Dengan pertimbangan harga tanah di Kelurahan Condongcatur yang sangat tinggi maka prosentase luasan RTH terimplementasi sebesar $50 \%$ atau lebih diasumsikan sebagai nilai tertinggi yang menyatakan kriteria implementasi RTH Sesuai dengan peraturan yang diberlakukan. Kemudian, berdasarkan professional judgment, prosentase luasan RTH terimplementasi kurang dari separuh diasumsikan sebagai nilai terendah yang menyatakan kriteria implementasi RTH di perumahan. Tidak Sesuai dengan peraturan yang diberlakukan. Kemudian prosentase luasan RTH terimplementasi antara $26 \%$ sampai dengan $49 \%$ dianggap belum mengimplementasikan kebijakan dengan baik yang kemudian diurutkan dengan nilai interval 8 yang memiliki kriteria implementasi Kurang Sesuai sampai dengan Cukup Sesuai secara berurutan seperti ditunjukkan pada Tabel 2.

Tabel 2. Kriteria Implementasi Kebijakan Penyediaan RTH Perumahan di Kabupaten Sleman

\begin{tabular}{|c|c|c|}
\hline No. & $\begin{array}{c}\text { Prosentase Luasan RTH } \\
\text { Terimplementasi }\end{array}$ & Kriteria Implementasi \\
\hline 1. & $\leq 25 \%$ & Tidak Sesuai \\
\hline 2. & $26 \%-33 \%$ & Kurang Sesuai \\
\hline 3. & $34 \%-41 \%$ & Agak Sesuai \\
\hline 4. & $41 \%-49 \%$ & Cukup Sesuai \\
\hline 5. & $\geq 50 \%$ & Sesuai \\
\hline
\end{tabular}

Hasil pengelompokan pada kriteria tersebut kemudian dianalisa secara deskriptif kualitatif dibandingkan dengan hasil studi literatur, wawancara dan pengamatan langsung di lapangan yang kemudian menjadi kesimpulan akhir dari penelitian ini.

\section{HASIL DAN PEMBAHASAN}

Berdasarkan survei yang dilakukan maka hasil pendataan sampel perumahan dengan metode Stratified Proportional Random Sampling dapat dilihat pada Tabel 3 berikut ini. 
Tabel 3. Pendataan sampel penelitian berdasarkan Stratified Proportional Random Sampling

\begin{tabular}{|c|c|c|c|c|c|c|c|}
\hline No. & Nama Perumahan & $\begin{array}{c}\text { Tipe } \\
\text { Kavling } \\
\text { Terstrata }\end{array}$ & $\begin{array}{c}\text { Jumlah } \\
\text { Unit } \\
\text { Kavling }\end{array}$ & $\begin{array}{c}\text { Total } \\
\text { Unit } \\
\text { Kavling } \\
\text { per Tipe }\end{array}$ & $\begin{array}{c}\text { Prosentase } \\
\text { Proporsi } \\
\text { Sampel }\end{array}$ & $\begin{array}{c}\text { Jumlah } \\
\text { Sampel } \\
\text { Acak }\end{array}$ & $\begin{array}{c}\text { Total } \\
\text { Sampel } \\
\text { Acak per } \\
\text { Tipe }\end{array}$ \\
\hline 1. & Villa Kanaka Sejahtera & $75 \mathrm{~m}^{2}$ & 20 & \multirow{2}{*}{39} & \multirow{2}{*}{$30 \%$} & 6 & \multirow{2}{*}{12} \\
\hline 2. & Anggajaya Permai & $75 \mathrm{~m}^{2}$ & 19 & & & 6 & \\
\hline 3. & Mandiri Graha Yasa & $100 \mathrm{~m}^{2}$ & 22 & \multirow{3}{*}{36} & \multirow{3}{*}{$28 \%$} & 6 & \multirow{3}{*}{10} \\
\hline 4. & Citra Parama 2 & $100 \mathrm{~m}^{2}$ & 8 & & & 2 & \\
\hline 5. & Alam Tiara Chisa & $100 \mathrm{~m}^{2}$ & 6 & & & 2 & \\
\hline 6. & Puri Adi Citra & $200 \mathrm{~m}^{2}$ & 22 & \multirow{3}{*}{45} & \multirow{3}{*}{$34 \%$} & 7 & \multirow{3}{*}{15} \\
\hline 7. & Cempaka Mulia & $200 \mathrm{~m}^{2}$ & 12 & & & 4 & \\
\hline 8. & $\begin{array}{l}\text { Pastika Condongcatur } \\
\text { Residence }\end{array}$ & $200 \mathrm{~m}^{2}$ & 11 & & & 4 & \\
\hline 9. & Mitra Land Estate & $300 \mathrm{~m}^{2}$ & 10 & 10 & $8 \%$ & 1 & 1 \\
\hline & Jumlah & & & 130 & & & \\
\hline
\end{tabular}

Berdasarkan hasil survey di lapangan maka data-data yang terkumpul diolah dan dipresentasikan pada Tabel 4 berikut ini.

Tabel 4. Pendataan Hasil Survei Lapangan dan Pengolahan Data

\begin{tabular}{|c|c|c|c|c|c|}
\hline $\begin{array}{c}\text { Tipe } \\
\text { Unit } \\
\text { Kavling } \\
\text { Terstrata }\end{array}$ & $\begin{array}{c}\text { Nama } \\
\text { Perumahan }\end{array}$ & $\begin{array}{c}\text { Jumlah } \\
\text { Sampel } \\
\text { Acak }\end{array}$ & $\begin{array}{c}\text { Prosentase } \\
\text { Sampel Acak } \\
\text { yang Memiliki } \\
\text { RTH }\end{array}$ & $\begin{array}{c}\text { Rata-rata } \\
\text { Prosentase RTH } \\
\text { Terimplementasi }\end{array}$ & $\begin{array}{l}\text { Keberadaan RTH di } \\
\text { Luar Kavling }\end{array}$ \\
\hline $\mathbf{m}^{2}$ & & unit & $\%$ & $\%$ & \\
\hline \multirow[b]{2}{*}{75} & $\begin{array}{l}\text { Villa Kanaka } \\
\text { Sejahtera }\end{array}$ & 6 & 100 & 4,0 & $\begin{array}{l}\text { Ada; Sebagai taman } \\
\text { berbentuk linier di depan } \\
\text { pintu masuk perumahan }\end{array}$ \\
\hline & $\begin{array}{l}\text { Anggajaya } \\
\text { Permai }\end{array}$ & 6 & 100 & 9,3 & $\begin{array}{llr}\text { Ada; } & \text { Berupa } & \text { kebun } \\
\text { dengan } & \text { tanaman } & \text { liar di } \\
\text { bagian } & \text { belakang } \\
\text { perumahan } & \end{array}$ \\
\hline \multirow[b]{3}{*}{100} & $\begin{array}{l}\text { Mandiri Graha } \\
\text { Yasa }\end{array}$ & 6 & - & - & $\begin{array}{l}\text { Ada; Sebagai taman } \\
\text { berbentuk linier di depan } \\
\text { pintu masuk perumahan }\end{array}$ \\
\hline & Citra Parama 2 & 2 & 50 & 2,5 & Tidak ada. \\
\hline & $\begin{array}{l}\text { Alam Tiara } \\
\text { Chisa }\end{array}$ & 2 & 100 & 8,0 & $\begin{array}{l}\text { Ada; Berupa tanah } \\
\text { kosong berbentuk linier di } \\
\text { bagian tengah perumahan } \\
\text { yang rencana awalnya } \\
\text { akan dibangun taman. }\end{array}$ \\
\hline
\end{tabular}




\begin{tabular}{|c|c|c|c|c|c|}
\hline $\begin{array}{c}\text { Tipe } \\
\text { Unit } \\
\text { Kavling } \\
\text { Terstrata }\end{array}$ & $\begin{array}{c}\text { Nama } \\
\text { Perumahan }\end{array}$ & $\begin{array}{c}\text { Jumlah } \\
\text { Sampel } \\
\text { Acak }\end{array}$ & $\begin{array}{c}\text { Prosentase } \\
\text { Sampel Acak } \\
\text { yang Memiliki } \\
\text { RTH }\end{array}$ & $\begin{array}{c}\text { Rata-rata } \\
\text { Prosentase RTH } \\
\text { Terimplementasi }\end{array}$ & $\begin{array}{l}\text { Keberadaan RTH di } \\
\text { Luar Kavling }\end{array}$ \\
\hline \multirow{3}{*}{200} & Puri Adi Citra & 7 & 100 & 12,2 & $\begin{array}{l}\text { Ada; Sebagai taman } \\
\text { berbentuk linier di depan } \\
\text { pintu masuk perumahan }\end{array}$ \\
\hline & Cempaka Mulia & 4 & 50 & 5,8 & $\begin{array}{llr}\text { Ada; } & \text { Berupa } & \text { tanah } \\
\text { kosong } & \text { di depan } & \text { pintu } \\
\text { masuk } & \text { yang } & \text { rencana } \\
\text { awalnya } & \text { akan } & \text { dibangun } \\
\text { taman. } & & \\
\text { anal }\end{array}$ \\
\hline & $\begin{array}{l}\text { Pastika } \\
\text { Condongcatur } \\
\text { Residence }\end{array}$ & 4 & - & - & $\begin{array}{l}\text { Ada; Sebagai taman } \\
\text { berbentuk linier di depan } \\
\text { pintu masuk perumahan } \\
\text { dan berupa taman di } \\
\text { bagian tengah perumahan. }\end{array}$ \\
\hline 300 & $\begin{array}{l}\text { Mitra Land } \\
\text { Estate }\end{array}$ & 1 & 100 & 12,0 & $\begin{array}{l}\text { Ada; Sebagai taman } \\
\text { berbentuk linier di depan } \\
\text { pintu masuk perumahan }\end{array}$ \\
\hline
\end{tabular}

Berdasarkan Tabel 3 dan Tabel 4, dapat dilihat bahwa dari populasi perumahan di Kelurahan Condongcatur terdapat 44,4\% (4 perumahan) memiliki luas kavling $\geq 125 \mathrm{~m}^{2}$ dan 55,6\% (5 perumahan) memiliki luas kavling $\leq 125 \mathrm{~m}^{2}$. Hal ini mengindikasikan bahwa pengembang perumahan masih cenderung mengabaikan ketentuan luas kavling minimal $125 \mathrm{~m}^{2}$ untuk memperbanyak jumlah unit kavling yang memberi keuntungan ekonomi lebih tinggi.

Dari total populasi perumahan yang memenuhi syarat luas kavling minimal, 25\% (1 perumahan) merupakan perumahan berskala besar dan 75\% (3 perumahan) merupakan perumahan berskala menengah. Pada perumahan berskala besar, terdapat 100\% sampel disediakan RTH di kavlingnya oleh developer dengan rata-rata prosentase luasan 12,2\% dari luas kavling dan RTH tersebut tidak dirubah menjadi lahan terbangun oleh pemiliknya. Pengembang juga menyediakan RTH di luar kavling yang menjadi taman di pintu masuk perumahan. Pada perumahan berskala menengah, $33,3 \%$ (1 perumahan) terdapat 100\% sampel disediakan RTH di kavlingnya oleh developer dan tidak diubah menjadi lahan terbangun oleh pemiliknya serta disediakan RTH di luar kavling yang menjadi taman di pintu masuk perumahan, 33,3\% (1 perumahan) terdapat 50\% sampel yang masih mempertahankan RTH sebagaimana fungsinya, dan 33,3\% (1 perumahan) terdapat 100\% sampel yang tidak disediakan lahan untuk RTH di kavlingnya namun disediakan lahan RTH di luar kavling berupa taman di depan pintu masuk dan taman di bagian tengah perumahan. 
Sedang dari total populasi perumahan yang tidak memenuhi syarat luas kavling minimal, 60\% merupakan perumahan berskala besar dan 40\% merupakan perumahan berskala kecil. Pada perumahan berskala besar, 66,7\% (2 perumahan) terdapat 100\% sampel yang disediakan RTH oleh developer di kavlingnya dan masih tetap dimanfaaatkan sebagai RTH oleh para pemiliknya dan $33,3 \%$ (1 perumahan) terdapat $100 \%$ sampel tidak disediakan lahan RTH di kavlingnya namun disediakan RTH di luar kavling yaitu sebagai taman di pintu masuk perumahan. Pada perumahan berskala kecil, 50\% (1 perumahan) terdapat 100\% sampel disediakan lahan RTH oleh developer dan RTH tersebut tidak dirubah pemanfaatannya serta disediakan RTH di luar kavling namun hanya berupa tanah kosong yang terbengkalai di bagian belakang perumahan dan $50 \%$ (1 perumahan) terdapat 50\% sampel yang masih memanfaatkan RTH sesuai fungsinya dan sayangnya tidak disediakan lahan RTH di luar kavling sama sekali.

Dilihat dari angka-angka tersebut dapat terlihat adanya indikasi kesadaran yang cukup tinggi dari pengembang perumahan berskala besar untuk menyediakan RTH di dalam maupun di luar kavling dan jug terlihat adanya kesadaran dari pemilik kavling untuk mempertahankan RTH sebagaimana fungsinya. Pada perumahan berskala menengah, kesadaran pengembang untuk menyediakan RTH masih bervariasi dari rendah sampai tinggi dan kesadaran pemilik kavling untuk mempertahankan RTH sesuai fungsinya juga bervariasi. Pada perumahan berskala kecil, kesadaran pengembang maupun pemilik hampir sama dengan karakter pengembang dan pemilik pada perumahan berskala menengah.

Analisis kesesuaian rata-rata prosentase RTH yang diimplementasikan pada tiap tipe kavling dan kriteria implementasinya dipresentasikan pada Tabel 5 berikut ini.

Tabel 5. Rata-rata prosentase RTH terimplementasi dan kriteria implementasi

\begin{tabular}{|c|c|c|}
\hline Tipe Luas Kavling & $\begin{array}{c}\text { Rata-rata Prosentase RTH } \\
\text { Kavling Terimplementasi per } \\
\text { Tipe Kavling }\end{array}$ & $\begin{array}{c}\text { Kriteria } \\
\text { Implementasi RTH Kavling }\end{array}$ \\
\hline Tipe $75 \mathrm{~m}^{2}$ & $6,7 \%$ & Tidak Sesuai \\
\hline Tipe $100 \mathrm{~m}^{2}$ & $2,1 \%$ & Tidak Sesuai \\
\hline Tipe $200 \mathrm{~m}^{2}$ & $7,5 \%$ & Tidak Sesuai \\
\hline Tipe $300 \mathrm{~m}^{2}$ & $12,0 \%$ & Tidak Sesuai \\
\hline
\end{tabular}

Dalam hal penyediaan RTH di setiap unit kavling perumahan, keseluruhan sampel menunjukkan implementasi yang Tidak Sesuai dengan standar yang diberlakukan Peraturan Bupati Sleman 
Nomor 11 Tahun 2007 tentang Pengembangan Perumahan karena RTH kavling yang terimplementasi berada jauh di bawah $25 \%$. Hal tersebut mengindikasikan bahwa kebanyakan pengembang cenderung mengabaikan ketentuan nilai KDB maksimal 50\% untuk mengoptimalkan lahan menjadi bangunan rumah.

\section{DAFTAR PUSTAKA}

Amin, S. \& Amri, N., 2011, Evaluasi Ketersediaan Ruang Terbuka Hijau Di Kompleks Perumahan Bumi Permata Sudiang Kota Makassar, Prosiding Hasil Penelitian Fakultas Teknik UNHAS Volume 5 : Desember 2011 Group Teknik Arsitektur, ISBN : 978-979-127255-0-6

Asdak, C., 2010, Hidrologi, Fifth Edition, Gadjah Mada University Press, Yogyakarta

DPPD Sleman, 2012, Hasil Penelitian, Kajian Akademis Pengendalian Perumahan Tahun 2012

Dwiyanto, A., 2009, Kuantitas dan Kualitas Ruang Terbuka Hijau di Permukiman Perkotaan. Jurnal Teknik Volume 30 No. 2, ISSN 0852-1697 hal.88-92

Fandeli, C., Kaharuddin \& Mukhlison, 2004, Perhutanan Kota, Fakultas Kehutanan Universitas Gadjah Mada, Yogyakarta

Kodoatie, R.J. \& Sjarief, R., 2010, Tata Ruang Air, Penerbit ANDI, Yogyakarta

Nandi, 2008, Mengatasi Masalah Lingkungan Perkotaan Melalui Optimalisasi Pengelolaan Ruang Terbuka Hijau, Prosiding Seminar Nasional Pertemuan Ilmiah Tahunan IX IGI 